\title{
The Comparative Study of Brand Business Model of Chinese and \\ Foreign Travel Agency
}

\author{
Ying Meng ${ }^{1}$ \\ ${ }^{1}$ Xi'an International University, Xi'an, Shaanxi, 710077
}

KEYWORDS: Travel Agencies; Brand; Business Model

\begin{abstract}
American Express and China International Travel Service, for example, analysis of China Travel brand management mold problems raised optimizing China Travel brand business model strategy. Key American Express brand management model of the success lies a strong brand awareness and accurate brand positioning, improve brand structure, branding, extensive and efficient brand management, timely brand expansion, China International Travel Service brand business model is more successful It depends on the modern mode of operation, management and price monopoly price positioning. Compared with the Express Company, lack of brand awareness China Travel brand management, business philosophy immature to form a scale. Chinese travel agency brand business model from the need to establish brand awareness and start operating characteristics, enhance enterprise competitiveness; pay attention to establish a corporate image market, improve enterprise management level, the scale of business model; brand building strategic alliances to strengthen the brand and related industries strategic cooperation.
\end{abstract}

\section{Introduction}

Brand is an important part of modern enterprise development, especially after China's accession to the WTO, the government opened the tourism market, a large number of joint venture travel agencies into the domestic tourism market. Travel agency has become fully liberalized market industry trends, foreign travel agencies using the existing brand advantage to seize a large number of tourism market. So far, most of the interior is also large tourist group travel through constant mergers, restructuring and adjustment, etc. combination to optimize the operation and management of the brand, to build a strong brand travel agencies, travel agencies cope with the impact of foreign brands. However, there is a significant gap between the strength of domestic travel agencies and travel brands and foreign brands, brand management issues outstanding travel agents [1]. With a steady flow of foreign capital into the country, domestic travel agencies must optimize brand management mode, in order to better respond to challenges.

\section{Contrast the Successful Experience of Chinese and Foreign Travel Agency Brand Business Model}

United States Express Company was founded in the 1850s, tourism has offices in hundreds of countries, with ten million merchants, is the world's largest travel service company, world-renowned. AmEx key to success lies in brand management and brand strategy and marketing strategy.

First, establish brand awareness. Express claims that the company's mission is to become the world's most respected service brand, companies only conduct conducive to enhance corporate 
brand business. As can be seen from the Express company's business, the company attaches importance to establish a world-class brand. Second, accurate brand positioning. Express Company from the consumer's point of view, accurate periodic brand formula, as the basis for determining brand should have the properties and performance - trust, honesty, service, quality, and management of any business decisions companies need to carry out in line with the brand attributes and performance, has become the brand attributes of all indicators and decision-making work of the enterprise. Third, improve the brand structure. In a large number of business practice, the company constantly improve the brand structure, brand structure adjustment for different users and user needs. Fourth branding. AmEx not only through traditional advertising brand image, but also because the user to promote its brand connotation, improve brand reputation, to establish a balance between customer expectations and actual service; the fifth is the brand expansion. After the AmEx brand management success and into the interests of the company's brand gradually to credit cards and other financial products to expand the field, and take the road of brand management diversification. Sixth brand management. The creation date, the company has always taken Express brand management as the core strategy to target customers push premium services to enhance brand awareness. Target customers, AmEx design advanced customer management systems, and enhance customer service quality control, the brand continued to grow for the company to provide important protection.

China International Travel Service was established in the 1950s, to the early days of the reform and opening period, CITS belonging to government departments, then engaged in political work, do not have the economic attributes. After the reform and opening up, China's tourism market began to take shape and continue to develop the business scope International Travel Service continues to expand, with the monopoly to achieve rapid development [2]. So far, CITS World Tourism Organization, only one member of Chinese enterprises, CITS trademark of the State Trademark Bureau finds that well-known trademarks in China tourism, but also access to national franchise outbound tourism travel agency. Combined with CITS development process, the key to success in the following points.

First, monopoly. Travel agencies belong to the early days of government departments, has a unique advantage in business development. Affected historical reasons, more than thirty years after the establishment of travel agencies operating in monopolistic situation objectively lead to CITS become well-known brands. Second, improve the brand structure. Monopoly operating as the company formed a sound brand structure provides a good condition. China Travel Service has been carried out, the situation of tourism, tourism from ordinary to high-end business travel, from special tourism to mass tourism, International Travel Service can provide satisfactory service brand; Third, the market price positioning. In "Global Line" brand, for example, by CITS mode and network mode of operation, to minimize the cost of the global row, guests enjoy the lowest prices of the most attractive global tourist experience. Fourth, the modern mode of operation. "Global Line" mode of operation and modernization and international integration, purchasing, sales, operations are to achieve unity.

\section{China Travel Brand Management Problems}

Travel brand belongs to the scope of the concept, is the vast number of consumers of travel products and services a comprehensive concept, combined with China International Travel Service brand business model, the domestic travel agency brand business model following problems.

First, the travel agency business stay in the low-level price competition and inefficient duplication, not yet formed a travel agency characteristic brands. Second, the travel agency did not 
pay attention to staff training brand value training, learn from other travel agencies completely brand concept, unbound enterprise characteristics "Qucuqujing"; and finally, market positioning travel route is limited to mature, is not conducive to cultivate brand awareness [3]. Due to the lack of brand awareness travel, domestic travel level uneven levels, and the emergence of "sub-standard goods drives out good" bad situation.

Most travel agencies lack "people-oriented" business philosophy, only care about immediate course of business, we have not seen the full long-term value of the customer, resulting in tourism products and services do not pay attention to the customer experience. Unable to get attention to customer experience, but also can not form a travel brand awareness.

The quantity and quality of travel agencies have a significant gap with foreign countries, the main cause of this situation is that the emphasis on short-term benefits travel agents, ignoring long-term development. Missing link between travel agencies, neglect integrated marketing, and therefore can not form scale operation. Such as CYTS, China International Travel Service, China Comfort Travel Service and other well-known domestic brand group functionality loose.

\section{China Travel Brand Management Strategy}

Excellent travel agency can only help travel brands occupy a larger tourism market, travel agencies have even broader room for expansion, access to capital operation efficiency field, and property transactions. Combining foreign travel agency brand business model and its own brand business model problems of China's travel agencies to implement brand management model should focus on the following points.

Knowledge economy era, the brand is an important asset, the brand value of the enterprise operation and development continues to improve. In recent years, the operators come to realize the value of brand management, and initially establish a sense of brand management [4]. On this basis, travel agents need to constantly expand freedom brand management, brand management system integrated into travel business development strategy, enhance the status and role of brand management from the recognition, prompting operators to take the initiative to form the brand philosophy, led to an intensive change travel direction promote a brand management, improve the quality of travel products and travel services.

Well-known brand prestigious key is to form a set of characteristics of business model expertise, business characteristics of business model mainly from high-quality free brand. Corporate management approach from "have" gradually "excellent" transition. Travel agencies need to carry out business based on their target market and regional characteristics, in order to focus on the formation of commodity operating characteristics [5]. At the same time, the creation of free brand, the formation of product characteristics, improve product attractiveness to customers, enhance the market competitiveness of travel agencies.

Brand is the product quality and credibility of the specific commodity market performance, premium brands can bring higher brand investment effect for the enterprise. The brand also reflects the company's market image and quality, demonstrating the potential of enterprise development. China's travel agencies need to develop its own brand, image and change the external manifestations of travel services, using its own brand to establish a good reputation in the market, then convert customer acceptance of tourism products and services, so that the quality of tourism services and competition into tourism brand competition, in order to highlight the external travel market image [6].

Brand as a market mainly in the form of corporate image and quality, good brand can enhance self-confidence and pride, encourage enterprises to take the initiative to maintain the brand image of 
the market. Therefore, travel agents need to imbue the staff of its own brand concept, improve staff management initiative to ensure the quality of travel products and services based on a common market, to maintain their own image and enhance the management level. At the same time, travel agencies should be its own brand as the core, enhance the cohesion of the travel agency.

Brand strategic alliance refers to the formation of a strategic alliance between travel agents and travel agencies and related industries. Establish strategic alliances may be formed between the virtual business travel and it features its own weaknesses to other travel agencies to complete the joint development, the launching of tourism products, develop new markets, thereby obtaining scale advantages. Moreover, domestic and foreign travel agencies travel agencies also work together to implement international operations. The way there was not only the division of labor, division of labor and cooperation exist, and foreign travel agencies can form complementary advantages, make a simple competition between travel agencies shift to cooperative competition [7]. For example, Shanghai "individual travel supermarket", the brand by the 18 small travel agency, which formed a unified brand, price, service and commitment to gradually break the dominance of foreign well-known travel agency in the country.

In 1996 American Express Company and Microsoft to cooperate, develop interactive American Express Travel online booking system for visitors to provide more convenient online services, has prompted a shift in the concept of tourists. Through the online ticketing system, American Express Company for different customer group demand more in-depth understanding customer needs by studying the introduction of different brands, optimize the allocation of resources, enhance the company's competitiveness. Science and Technology Development will travel to modern business transformation business model, travel agents ability to process information and service delivery capability should also continue to provide. But their ability to travel cannot meet the needs of social development, and therefore the need to strengthen cooperation with travel agencies tourism-related industries.

\section{Conclusion}

All in all, travel agencies to carry out the brand business model is the inevitable requirement of the development of the industry. Travel agencies need to establish a people-oriented long-term development of consciousness, and strengthen brand management philosophy, its own brand will incorporate the entire process of travel agency business, driven economic paradigm shift travel agencies, travel goods and improve service quality, enhance the market competitiveness of travel agencies.

\section{REFERENCE:}

[1] Ran Xiangyun. Shanghai Spring International Travel Service Brand Strategy [D]. Jilin University, 2008.

[2] Geng Wenwen. comparative study American and Chinese Travel Brand Management [J]. Journal of Hebei Tourism Vocational College, 2008,02: 21-25.

[3] Liu Wenhui. Summary of tourism brand building [J]. Market Weekly (theory), 2013,06: 61-64 + 100.

[4] Sun Junzhe, Li Bin. Chinese and foreign travel agency management model were compared [J]. Changchun College of Education, 2013,09: 32-33.

[5] Wu Jianxing. domestic travel industry brand management [J]. Harbin University of Commerce (Social Science Edition), 2010,02: 88-92. 
[6] Wu Jianxing. domestic travel industry brand management research [J]. Shaanxi Agricultural Sciences, 2012,04: 159-162 + 184 .

[7] Zhu Mingyuan. business strategy of the Spring International Travel Service [J]. Nanjing Radio and Television University, 2009,02: 81-85. 